https://doi.org/10.18485/iipe_response2covid19.2021.ch24

\title{
FROM A NATIONAL CRISIS TO STRATEGIC OPPORTUNITIES? CHINA'S STATE RESPONSE TO COVID-19 AND MAJOR-POWER DIPLOMACY
}

\begin{abstract}
Yoshikazu Kato ${ }^{1}$
Abstract: The early stages of COVID-19 put the Chinese Communist Party (CCP) on the defensive as its response appeared to undermine public trust and confidence at home, later spurring criticism around the world. Since then, the CCP leadership has been quite concerned about three scenarios the state might possibly confront: economic recession, social panic, and diplomatic isolation. These mattered for the CCP's legitimacy as well as the survival of the state.

In fact, the CCP contained the spread of the virus, recovered the economy successfully compared to most of the Western governments, including the United States, using every measure they could.

As the coronavirus began spreading to other countries, and China's draconian lockdown strategy yielded positive results, the CCP turned its attention to international diplomacy, showing how the CCP enhanced its international influence, converting the national crisis into strategic opportunities by supplying medical devices and protective equipment, sharing know-how and cooperating with international agencies.

Major-power diplomacy under Xi Jinping's leadership will see China taking advantage of the pandemic to engage in standard setting and rulemaking for global governance. Mask and vaccine diplomacy have been part of the CCP's strategic effort to ensure its legitimacy internationally. Beijing understands that if it is seen as a world leader, and Washington is seen as unable or unwilling to do so, this could fundamentally alter the US's position in global politics and the contest for leadership in the twenty-first century.

Keywords: Chinese Communist Party (CCP), COVID-19, Xi Jinping, major-power diplomacy
\end{abstract}

\footnotetext{
${ }^{1} \mathrm{PhD}$, director of Trans-Pacific Group and research fellow of Rakuten Securities Economic Institute, Tokyo, Japan, kato.yoshikazu@transpacificgp.com.
} 


\section{CHINA'S EARLY-STAGE RESPONSE TO COVID-19 AND ITS CONCERNS}

The CCP's initial response to and management of COVID-19 sparked widespread debate both domestically and internationally. The reasons which triggered widespread scepticism and criticism, this paper argues, have been deeply rooted in the General-Secretary of the CCP, Xi Jinping's policies under his absolute leadership, and the consolidated power foundation.

While the first case occurred on December 8, 2019, and possibly even earlier, in Wuhan city, the capital of Hubei province, the municipal government did not tackle the potential crisis nor begin to address the problem until January 20, 2020, when Xi ordered that action be taken to control the coronavirus (Buckley, Myers, 2020). On that day, the central and local governments, for the first time, officially recognized the existence and danger of the coronavirus. The lockdown was instituted in Wuhan only on January 23 - seven weeks after the coronavirus first appeared. By then, Mayor Zhou Xianwang admitted that more than five million people had fled from Wuhan.

Politics, as always, did matter in tackling COVID-19 within the party. Since the outbreak and spread of the coronavirus, the localities have been blamed for delays in reporting new cases. The leadership in Wuhan and Hubei was forced to take responsibility for the incident. As a result, the central government sacked Jiang Chaoliang, the party secretary of Hubei province, and Ma Guoqiang, the party secretary of Wuhan city. Their dismissals may not have been fair - we cannot judge because there has been no open accounting of the crucial early period in Wuhan and how local officials interacted with Beijing. But it is evident from a dispassionate assessment of the way the crisis unfolded that the local officials do not bear the sole responsibility (Mcgregor, 2020).

The most structural and fundamental reason for the delayed responses by the local leadership to the spread of the coronavirus in Wuhan, this paper argues, originated in Xi's over-consolidated power in the central government rather than transferring certain extents of powers and rights to the local governments. The outcome of this structural complex has been the spread of "fear politics". Everybody, including very senior officials, such as the party secretary of Wuhan and Hubei, is scared in front of Xi, eager to avoid making mistakes, being forced to just report the goodness and success of the CCP's governance across the nation.

Under this political reality, the localities did not have enough incentives to report negative information about the unusual virus to the central government in the early stages. It is still unclear what kind of communication was implemented between Wuhan and Beijing from December 2020 to January 2021. But it was undeniable that Xi's politics with over-consolidated power has structurally affected the delayed 
response by the localities in the early stage. The tension between Xi's concentration of individual powers and China's past practice of collective leadership has become especially significant at a time when the country is confronting many daunting challenges (Li, 2016, p. 24). COVID-19, in this sense, is undoubtedly unexceptional.

Once Xi made a decision and announced to "go ahead", the CCP tried to contain the spread of the coronavirus by using every measure they could. China's battle against COVID-19 was essentially a state-mobilized movement. From state-run organizations to online groups to big businesses, nearly all elements of civil society have moved swiftly into action. They donated money, organized food delivery, built health apps, and distributed masks and other equipment. Working in concert with government agencies, these various groups mobilized like various crew teams on a gigantic ship in peril (Fu, 2021).

In terms of the CCP's concerns about its legitimacy crisis, particularly a potential risk of losing the public trust domestically, one seminal incident was the death of Dr Li Wenliang, a Chinese ophthalmologist at the Wuhan Central Hospital. Li warned his colleagues on December 30,2019, about the possible outbreak of an illness that resembled severe acute respiratory syndrome (SARS) on a WeChat group.

Then Li was summoned and admonished by the local Wuhan police. Finally, he was infected with the coronavirus in the hospital and died on February 7, 2020. Just after his death, much dissatisfaction and complaint about the government appeared on the Chinese version of Twitter, and some users even demanded freedom of expression. But eventually, the CCP leadership successfully contained these turbulent opinions, and people stopped challenging the authority of the CCP. ${ }^{2}$

There had been obvious evidence to prove why the authorities were surely upset. After Li's death, the government launched an investigation into Li's case immediately. This was quite unusual in the history of Chinese politics. The motivations of the authorities to do this vividly reflected Xi's political anxieties, which might possibly trigger citizens' resentments against the authorities. China Daily, the mouthpiece of the CCP, acknowledged that Li's death had triggered great sorrow

\footnotetext{
${ }^{2}$ According to the BBC's investigative report, while the authorities have since officially recognized Dr Li Wenliang as a "martyr", several notable activists may be written out of the country's COVID-19 history. During the Wuhan outbreak, a number of citizen journalists made a notable impact internationally, by circumventing the "great firewall of China" to get word out of the city. These include Chen Qiushi, Fang Bin and Zhang Zhan. They racked up hundreds of thousands of views on YouTube for videos that they said gave the true picture of what was happening in Wuhan. However, this came at a cost. The Committee to Protect Journalists notes that in Wuhan, the authorities "arrested several journalists for coverage that threatened the official narrative of Beijing's response". (BBC, December 29, 2020).
} 
among the public, and many people believed he was wrongfully accused of "spreading rumours". On the same day, the National Supervisory Commission decided to send a team to Wuhan to investigate issues regarding his death. About a month later, a report of the investigation released on March 19 stated that Li made a positive contribution to epidemic control work, and the local public security authorities should revoke the letter of reprimand issued to Li and apologize to his family (China Daily, 2020).

Beyond that, Li and 13 other people who died on the front line fighting the novel coronavirus in Hubei were identified as the first batch of martyrs on April 2. Martyrs are the highest honorary title which the party and state award to citizens who bravely sacrifice their lives for the nation, society and the people (CGTN, 2020).

After overcoming Li's case at the peak of the potential crisis of the nation and party's legitimacy, the CCP's next targets were simultaneously realizing virus containment and economic restoration. Since then, in fact, Xi has contained the spread of the coronavirus and recovered the economy successfully compared to Western governments, including the United States.

According to the statics calculated by the National Health Commission of the PRC, 87,071 people were infected by the novel coronavirus and 4,634 people died because of the virus. Given the statistics, the peak of the number was in February, 68,033 and 2,611. After that, the numbers decreased from June to December, and even stayed at zero (National Health Commission, 2020).

Economically, according to the National Bureau of Statistics, China expanded by $2.3 \%$ in 2020 . Roaring back from a historic contraction of $6.8 \%$ in the $1^{\text {st }}$ quarter of the year (then grew 3.2\%, 4.9\%, and 6.5\%), it became the only major world economy to grow in what was a pandemic-ravaged year (Cheng, 2021). As the International Monetary Fund (IMF) pointed out in the annual report published in December 2020 regarding the economic recovery under the pandemic, "growth is still unbalanced as the recovery has relied heavily on public support while private consumption is lagging. Rising financial vulnerabilities and the increasingly challenging external environment pose risks to the outlook. Important reforms have progressed despite the crisis, but unevenly across key areas. The Chinese economy continues its fast recovery from the health and economic crisis as a strong containment effort and macroeconomic and financial policy support have mitigated the crisis impact and helped the economy rebound" (IMF, 2020). ${ }^{3}$

\footnotetext{
${ }^{3}$ As key policies to secure the recovery and return to balanced growth in China, the IMF report raised the below suggestions: adjusting policy support to the recovery; making policy support more effective to maximize policy space; containing rising financial risks proactively; structural reforms to enhance the role of the private sector; leading global solutions.
} 


\section{FROM A NATIONAL CRISIS TO STRATEGIC OPPORTUNITIES}

At the early stage, Xi Jinping was surely concerned that the outbreak and spread of COVID-19 could bring about a national crisis and undermine the legitimacy of the CCP. By March, Xi was not holding back on the superlatives in describing the coronavirus epidemic and how serious a challenge it was.

As the most typical case, at a meeting to advance the work on coordinating the prevention and control of COVID-19 and economic and social development on February 23, 2020, Xi explicitly affirmed that "the COVID-19 outbreak is a major public health emergency that has spread at the fastest speed, caused the most extensive infection, and is the most difficult to contain in the country since the founding of the People's Republic of China". He also added that "this is both a crisis and a big test for us" (Xinhua, 2020).

This paper argues that, during that period, the CCP leadership was most concerned about three scenarios that the state might possibly confront: economic recession, social panic, and diplomatic isolation. If these three incidents happened simultaneously, legitimacy would not be possible in a crisis. This is the reason why the CCP tried to contain the spread of the coronavirus, and then to restore the economy as soon and as much as possible.

At that time, the authorities were still wondering what uncertainties remained to tackle the potential crisis. This mentality was reflected by the fact that the annual National People's Congress was unusually postponed for two months, and Premier Li Keqiang did not announce a goal of economic growth in 2020. Li noted, "We have not set a specific target for economic growth this year. This is because our country will face some factors in its development that are difficult to predict due to the great uncertainty regarding the COVID-19 pandemic and the world economic and trade environment" (Li, 2020). ${ }^{4}$

By the second quarter of 2020, the CCP has gradually but dynamically overcome the first two potential crises, economic recession and social panic, due to substantial achievements in containing the coronavirus (basically zero cases around June) and recovering the economy (3.2\% growth in the second quarter).

\footnotetext{
${ }^{4}$ According to Li, in 2020, China must give priority to stabilizing employment and ensuring living standards, win the battle against poverty, and specifically, set the following targets: over 9 million new urban jobs; a surveyed urban unemployment rate of around 6 percent; a registered urban unemployment rate of around 5.5 percent; CPI increase of around 3.5 percent; growth in personal income that is basically in step with economic growth; effective prevention and control of major financial risks etc.
} 
In comparison to these two, the CCP leadership is still concerned about diplomatic isolation, which might lead to China being condemned, if not isolated, by the international community, particularly democratic countries in the West.

Many political leaders around the world, particularly in the US, Australia, and Europe, have been critical of the CCP's lack of transparency in the early stages of the epidemic. This had implications for both China's neighbours and countries with which China has commercial and transport links. The complaints added to the fundamental mistrust that some Western countries already had of Xi's domestic and external policies, due in large measure to China's more forthright foreign policy of recent years. So-called "wolf-warrior" Chinese diplomats, who have riled host countries with their plainspoken talk, have become emblematic of that robust approach.

For its part, the CCP is insisting that its response to COVID-19 was fast and effective from the beginning, highlighting its willingness to share information, including the coronavirus genome, with the World Health Organization (WHO) as well as other national health authorities. Despite these claims, some countries, mainly in the West, have maintained their concerns about China's reliability, focusing on its relationship with the WHO as well as on the CCP's low level of transparency, slow response and evidence of attempts to suppress the spread of information about the coronavirus.

In the US, Republican Party lawmakers have introduced bills such as the Li Wenliang Global Public Health Accountability Act that would impose sanctions against China because of COVID-19. Along with the US, the Australian government and the European Union have raised questions about the origin of the coronavirus, proposing an independent scientific investigation into the matter. Beijing has rejected the idea, even warning that if Canberra pushed for an inquiry, Chinese consumers might have launched a boycott of Australian products. China later announced anti-dumping tariffs on Australian barley and suspended imports of beef from four abattoirs in the country.

As the coronavirus began spreading to other countries and China's draconian lockdown strategy yielded positive results, the CCP turned its attention to international diplomacy, became more confident and started behaving actively outside the border. Beijing's actions have showcased, as the paper discusses in the below part, China's major-power diplomacy which has been conducted in the Xi administration and the implications of this strategy (Kato, 2020).

In his speech on May 18, 2020, to the World Health Assembly, the governing forum of the World Health Organization (WHO), Xi Jinping gave robust defence of the Chinese handling of the coronavirus outbreak, insisting that they had acted with "openness, transparency and responsibility", added that "we have provided information to the WHO and relevant countries in a most timely fashion. We have 
released the genome sequence at the earliest possible time. We have shared control and treatment experience with the world without reservation. We have done everything in our power to support and assist countries in need" (Xi, 2020). He also pledged US\$2 billion toward the pandemic fight over the next two years, an offer in sharp contrast to US President Donald Trump's decision to withhold American funding from the $\mathrm{WHO}$ and his threat to leave the organization altogether.

There has been a precondition, or potential uncertainty, for the CCP to convert the national crisis into strategic opportunities. That is the coronavirus origin issue. China did not truly want to see and face a situation in which the international community collectively concluded that "the coronavirus has originated from China; that is Wuhan virus", and then forced China to take full responsibilities for the outbreak and spread of the coronavirus inside and outside China. If this scenario becomes a reality, China may even possibly have to pay huge amounts of compensation (something like war reparations) for lost growth and lives around the world under the pandemic. In this case, the legitimacy of the CCP would be in trouble both domestically and internationally.

In order to avoid this worst scenario, the CCP has conducted propaganda campaigns and united-front strategies, provided any data, information, and evidence to prove that China has not owed the world anything, but, on the contrary, made great contributions to save the health and lives on the planet. After almost a year since the outbreak of the coronavirus, Wang Wenbin, a spokesman for the Chinese Ministry of Foreign Affairs, commented on what China did at the regular press conference on December 29, 2020. He noted:

"There's a clear timeline of China's effort to fight COVID-19, which is open and transparent. At the earliest time possible, we reported the epidemic to the WHO, identified the pathogen and shared its genome sequence with the world, and we shared our information and containment experience with other countries and regions in a timely manner. These are facts that can stand the test of time. Accusations of "China covering up the epidemic" are simply groundless. I'd like to stress that China was among the first to have put the virus under control, to have resumed work and production, and to have realized economic stability and recovery. China enjoys stable and orderly socio-economic development, and our people enjoy safety, health and freedom. Faced with the once-in-a-century pandemic, can such achievements ever be made by covering up the truth? The answer is simple enough. China's achievements in fighting the pandemic are the best response to the fallacy of "China concealing the virus" (Wang, 2020).

For the CCP's struggle with the coronavirus origin issue, the unavoidable threat was coming from some Western countries, particularly the United States. This 
situation has never stopped, succeeded from the Trump administration to the Biden administration.

In May 2020, the Chinese government disclosed "Reality Check of US Allegations Against China on COVID-19", examined 24 cases $^{5}$ over China's response and tackling the coronavirus, tried to verify that what the US alleged was completely wrong, concluded that "recently, some US politicians and media outlets have been fabricating preposterous allegations and lies of one kind or another in order to shift the blame to China for their inadequate response to COVID-19. However, as Abraham Lincoln said, "You can fool all the people some of the time, and some of the people all the time, but you cannot fool all the people all the time". Lies evaporate in the light of truth. It is time to let the facts speak for themselves. In the future, we will continue to reveal the truth to the world whenever new lies appear" (Ministry of Foreign Affairs of China, 2020).

The CCP's diplomatic efforts to justify their fight against COVID-19 have persistently continued in 2021. From January 15 to February 10, the authorities strategically accepted the WHO team's visit to China and on-the-ground investigations into the origins of the coronavirus in Wuhan. After that, on March 31, the WHO released the "Report of Joint WHO-China Study of the Origins of SARSCoV-2" (WHO, 2021). Regarding the results of the investigation, the Chinese government commented that "The Chinese side offered necessary facilitation for the team's work, fully demonstrating its openness, transparency and responsible attitude" and "to politicize this issue will only severely hinder global cooperation in the study of origins, jeopardize anti-pandemic cooperation, and cost more lives. It would run counter to the international community's aspiration for solidarity against the virus" (Ministry of Foreign Affairs of China, 2021).

Obviously, China has intentionally relied on and taken advantage of the authority of the WHO's platform in order to accomplish its strategic objectives.

\footnotetext{
${ }^{5}$ As examples of China's counterarguments to the US allegations, pick up three cases below: 1. Allegation: Wuhan is the origin of the virus.-Reality Check: Being the first to report the virus does not mean that Wuhan is its origin. In fact, the origin is still not identified. Source tracing is a serious scientific matter, which should be based on science and should be studied by scientists and medical experts. 3.Allegation: The virus was constructed by the Wuhan Institute of Virology.-Reality Check: All available evidence shows that SARS-CoV-2 is natural in origin, not man-made. 16.Allegation: China controls the WHO.-Reality Check: China firmly supports multilateralism. We have always maintained good communication and cooperation with the WHO. But we have never attempted to manipulate the organization. The suspension of funding by the US, the largest contributor to the WHO, has been widely opposed by the international community.
} 
This is a continuation of China's traditional UN diplomacy. The CCP leadership considers the accountabilities of China's policies could have been maximized if they were well-performed within the UN platform where China is a member of its Security Council, and defined as mostly reflecting a real multilateralism and fairness in international relations.

Given this consideration, the authorities eventually insisted that "the WHO joint mission report has already reached a scientific and authoritative conclusion for the first phase of study" (Wang, 2021), rejecting any suspicions and criticisms of China's so-called delayed response and mismanagement with lack of transparency regarding the COVID-19 issues, including in the early stages. Since the outbreak and spread of the coronavirus, the CCP has periodically concluded that China has avoided the national crisis and should move on to increase the CCP's legitimacy and international influence by dynamically conducting major-power diplomacy in Xi's new era.

\section{IMPLEMENTATIONS OF MAJOR-POWER DIPLOMACY}

Chinese scholars have long defined major-power diplomacy as "diplomacy with major powers", referring to the US, Russia, and, in some cases, Japan. Under the Hu Jintao administration (2003-2012), China continued Deng Xiaoping's grand tactic of keeping a low profile and biding your time while also accomplishing things. Now, in Xi's new era, China has reoriented its course, practising diplomacy as a major power. (Kato, 2019). ${ }^{6}$

This paper argues that major-power diplomacy in Xi's new era consists of four aspects: economic expansion, political penetration, "friendship" creation, and core interest protection.

Since Xi took office, China has broadened its economic reach, leading to the establishment of institutions such as the Asian Infrastructure Investment Bank and increasing financial clout. Using its economic capabilities as a basis, China seeks to establish itself as a global political leader by enacting a multitude of international schemes. Through cultivating stronger economic and political ties with a large number of countries, China has assembled a formidable "friendship circle". These "friends" are strategic assets to protect China's core interests, which are constituted

\footnotetext{
${ }^{6}$ Yang Jiechi, director of the Central Foreign Affairs Commission and the $19^{\text {th }}$ Politburo, insisted "China is ready to shoulder its responsibility as a major country" at Study and Implement General Secretary Xi Jinping's Thought on Diplomacy in a Deep-going Way and Keep Writing New Chapters of Major-Country Diplomacy with Distinctive Chinese Features, July 17, 2017.
} 
by what China considers to be its inalienable positions; for example, its claims on Taiwan7, Hong Kong, Xinjiang, and the South China Sea. The CCP leadership has increasingly believed that it could not ensure the party's legitimacy without protecting the core interests. In this sense, COVID-19 provides a significant context for the CCP to test major-power diplomacy and increase its accountability eventually.

After focusing on national cohesion and shoring up government support at home, the CCP officials viewed COVID-19 as a strategic opportunity to influence other countries by supplying medical devices and protective equipment, sharing know-how, and cooperating with international agencies to increase the CCP's global legitimacy.

The CCP embarked on a campaign to counter criticism of its shortcomings in dealing with the virus and instead highlighted its contributions to the global pandemic fight and its role as a responsible major power on the international stage. "We would like to share China's best practices with other countries, but we will not turn them into any kind of geopolitical weapon or tool," Hua Chunying, a Foreign Ministry spokesperson, noted. "China would like to contribute our experience and ideas to global public health security and governance, which is something we should do as a responsible major country" (Hua, 2020).

Clearly, the CCP intends to use the context of COVID-19 to implement further major-power diplomacy. China is harnessing its economic capabilities by producing medical equipment such as protective gear and virus tests and supplying them to both developed and developing countries facing shortages. These efforts initially backfired when many items in initial shipments proved faulty or of low quality. Although so-called "mask diplomacy" in the relatively early stages was not so popular and even raised scepticism and hostility toward China's intentions and behaviour, China's efforts in vaccine development and diplomacy have accomplished certain outcomes and accountabilities.

\footnotetext{
${ }^{7}$ China has conducted aggressive policies towards Taiwan on the COVID-19 issues. On the call for Taiwan's willingness to participate in the 74th World Health Assembly, China, through diplomatic pressures on other countries, has successfully realized Taiwan's appearance to be rejected in the WHO-related platform, which the CCP has made a strategic point. According to Chinese Foreign Ministry Spokesperson's Remarks released on May 24, 2021, "we urge the DPP authorities to drop its attempt of seeking Taiwan independence by taking advantage of the epidemic, which will end up nowhere. We also urge certain countries to stop politicizing the health issue and stop interfering in China's internal affairs by playing up the Taiwan issue. Otherwise, they are doomed to fail just like a man who lifts a rock only to drop it on his own feet". Obviously, the CCP has tried to take advantage of the pandemic to impose pressure on Taiwan and eventually isolate it politically.
} 
As a strategic part of vaccine diplomacy, China joined a global scheme for the distribution of the COVID-19 vaccine - COVAX, backed by the WHO in October 2020. The COVID-19 vaccine, developed by Sinovac Biotech Ltd. and Sinopharm Group, was then approved by the WHO for emergency use listing, marking a significant advancement in vaccine diplomacy. In July 2021, the two Chinese developers agreed to sell their shots to the COVAX program, pledging millions of doses that would give the global distribution effort a much-needed boost. (Bloomberg, 2021). By July 12, 2021, China had provided 500 million vaccine doses and concentrates to over 100 countries and international organizations, one-sixth of the total global output (Zhao, 2021).

China is also seeking to expand its political influence by propagating the narrative that China is contributing to global public health. At the Global Health Summit held on May 21, 2021, Xi announced that China would continue to support global solidarity against COVID-19. He also promised that China would provide an additional 3 billion U.S. dollars in international aid over the next three years to support COVID-19 response and economic and social recovery in other developing countries (Xi, 2021).

At the same time, the CCP is stepping up its sharp criticism of the US - its response to the pandemic and its attempts to blame China for its predicament. Washington officials, including former president Donald Trump and his Secretary of State Mike Pompeo, pushed the narrative that the "Chinese virus" originated in a Wuhan laboratory. This stance has to some extent been adopted by the Biden administration. For instance, Biden has ordered intelligence officials to "redouble" efforts to investigate the origins of COVID-19, including the theory that it came from a laboratory in China (BBC, 2021).

Beijing has endlessly blamed the US for using that rhetoric. Hua Chunying said on May 7, 2020, "We urge the US to stop spreading disinformation and misleading the international community. It should reflect on its own problems and work hard to bring its own epidemic situation under control. It is high time that it gave up the blamedumping trick." (Hua, 2020). Regarding the statement that "some in the US are prompting the WHO to conduct a phase two investigation of COVID-19 origins targeting China" at the press conference on July 9, 2021, Wang Wenbin responded that "the overall situation of COVID-19 epidemics is increasingly pointing to multiple origins in multiple places. The mayor of Belleville, New Jersey, who has tested positive for coronavirus antibodies, said he was sick with the virus in November 2019, over two months earlier than the first confirmed case in the US and also earlier than the first case reported in China...The international community should reject all acts of political manipulation on origin-tracing, follow the WHO joint team's suggestion and 
conduct origin-tracing in multiple countries and regions to ensure effective prevention and preparedness in the face of future pandemics" (Wang, 2021).

Back in early 2020, while Trump continued to confound Americans and the world with his erratic handling of the pandemic, Xi was engaged in "friendship expansion" through "telephone diplomacy". According to the Chinese Ministry of Foreign Affairs, under the most critical circumstances in China, Xi held telephone meetings with other heads of state or government and UN officials 12 times in February, 11 times in March, 16 times in April in order to ensure the nation's reputation and credibility.

Major-power diplomacy will see China increasingly taking advantage of the pandemic to try to engage in standard-setting and rulemaking for global governance. "China's signature strength, efficiency, and speed in this fight has been widely acclaimed", Foreign Ministry spokesman Zhao Lijian declared at a press conference on March 5, 2020. "China set a new standard for the global efforts against the epidemic" (Zhao, 2020). ${ }^{8}$ In Xi's words, it was now time for China to embrace "big country diplomacy". And in remarks before the Politburo, Xi argued that he planned to "make China's voice heard, and inject more Chinese elements into international rules". Xi, more than any other post-revolutionary leader, staked the Communist Party's legitimacy on its ability to reclaim a leadership role on the global stage (Economy, 2018, p. 190).

\section{INSTEAD OF CONCLUSION: PROSPECTS ON COVID POLITICS}

Since Biden took office in January 2021, the United States, as well as other Western countries, have increasingly and collectively conducted stronger and tougher policies toward China in arenas such as human rights issues in Hong Kong and Xinjiang.

For example, at the G7 summit held in the UK in June 2021, the communiqué released by the leaders criticized China's assertive and repressive policies over Hong Kong and Xinjiang and reaffirmed their opposition to trade-distorting market abuses by the Chinese. The statement mentioned Taiwan for the first time. The statement mentioned Taiwan for the first time. However, under the current circumstances, the

\footnotetext{
${ }^{8}$ In an article published in Foreign Affairs in March 2020, US diplomat Kurt Campbell and Chinese scholar Rush Doshi argued that Beijing understands that if it is seen as leading, and Washington is seen as unable or unwilling to do so, this perception could fundamentally alter the United States' position in global politics and the contest for leadership in the twenty-first century.
} 
CCP leadership has been most concerned about whether the G7 leaders were pursuing responsibilities originating from the origins of COVID-19 toward China. ${ }^{9}$ The communiqué noted: "we also call for a timely, transparent, expert-led, and sciencebased WHO-convened Phase 2 COVID-19 origins study including, as recommended by the experts' report, in China". (Carbis Bay G7 Summit Communique, 2021). The CCP was closely watching how the leaders linked China with COVID-19.

The CCP under Xi's leadership and consolidated power foundation will continue to be highly cautious on the COVID-19 origin issue, oppose and reject any suspicion and criticisms of its responses and management. The issue will continue to be one of the most politically sensitive issues in the relationship between China and the West, particularly in the era of the US-China strategic rivalry. The Sino-American comprehensive competition will probably be the most significant geopolitical factor in international affairs for the next decade and beyond (Shambaugh, 2016, p.155).

Besides, the CCP will be extraordinarily concerned if the West unitedly boycotts attending the Beijing Winter Olympic Games, which will be held in February 2022, partly due to their complaints about China's state responses to the outbreak and spread of COVID-19. If this scenario becomes a reality, the CCP's legitimacy both in domestic and international society might be in trouble. At the same time, this might even undermine the processes and consequences of the $20^{\text {th }}$ Party Congress, scheduled for fall 2022 as one of the most important political events in recent years, and beyond.

\section{REFERENCES}

Allen, K., Feng, Z. (2020, December 29). China Covid-19: How state media and censorship took on coronavirus. BBC, retrieved from https://www.bbc.com/ news/world-asia-china-55355401. Accessed 5 July 2021.

BBC. (2021, May 27). Covid: Biden orders investigation into virus origin as lab leak theory debated, retrieved from https://www.bbc.com/news/world-us-canada57260009. Accessed 5 July 2021.

Bloomberg News. (2021, July 12). Global Vaccine Effort Leans on China to Overcome Setbacks, retrieved from https://www.bloomberg.com/news/articles/2021-0712/chinese-vaccine-makers-to-supply-doses-to-global-covax-program. Accessed 5 July 2021.

\footnotetext{
${ }^{9}$ Several government officials who are in charge of external relations, public security, trade, and commerce revealed that in the interview with the author in June 2021.
} 
Buckley, C., Myers, S.L. (2020, February 1). As New Virus Spread, China's Old Habits Delayed Fight. The New York Times, retrieved from https://www.nytimes.com/ 2020/02/01/world/asia/china-coronavirus.html. Accessed 1 July 2021.

CARBIS BAY G7 SUMMIT COMMUNIQUÉ. (2021, June). Our Shared Agenda for Global Action to Build Back Better, retrieved from https://www.consilium. europa.eu/media/50361/carbis-bay-g7-summit-communique.pdf. Accessed 1 July 2021.

CGTN. (2020, April 3). China recognizes Li Wenliang as a 'hero', condemns U.S. manipulation as 'extremely disrespectful', retrieved from https://news.cgtn. com/news/2020-04-03/Li-Wenliang-is-a-martyr-and-role-model-ChineseForeign-Ministry-Po9w3rC8SI/index.html. Accessed 1 July 2021.

Cheng, J. (2021, January 18). China Is the Only Major Economy to Report Economic Growth for 2020. The Wall Street Journal, retrieved from https://www.wsj. com/articles/china-is-the-only-major-economy-to-report-economic-growth-for2020-11610936187

Cui, J. (2020, March 20). Probe finds reprimand of doctor inappropriate. China Daily, retrieved from http://global.chinadaily.com.cn/a/202003/20/WS5e741294a 3101282172809ac.html

Economy, E. (2018). The Third Revolution-Xi Jinping and the New Chinese State. New York. Oxford University Press.

Foreign Ministry Spokesperson Hua Chunying's Regular Press Conference. (2020, April 3), retrieved from https://www.fmprc.gov.cn/mfa_eng/xwfw_665399/ s2510_665401/2511_665403/t1765751.shtml. Accessed 5 July 2021.

Foreign Ministry Spokesperson Hua Chunying's Regular Press Conference (2020, May 6). retrieved from https://www.fmprc.gov.cn/mfa_eng/xwfw_665399/ s2510_665401/t1776657.shtml. Accessed 1 July 2021.

Foreign Ministry Spokesperson's Remarks on Report of Joint WHO-China Study of Origins of SARS-CoV-2 Released by WHO. (2021, March 30), retrieved from https://www.fmprc.gov.cn/mfa_eng/xwfw_665399/s2510_665401/2535_6654 05/t1865603.shtml. Accessed 1 July 2021.

Foreign Ministry Spokesperson Wang Wenbin's Regular Press Conference. (2020, December 29), retrieved from https://www.fmprc.gov.cn/mfa_eng/xwfw_ 665399/s2510_665401/2511_665403/t1843191.shtml. Accessed 10 July 2021.

Foreign Ministry Spokesperson Wang Wenbin's Regular Press Conference (2021, July 9), retrieved from https://www.fmprc.gov.cn/mfa_eng/xwfw_665399 /s2510_665401/2511_665403/t1891109.shtml. Accessed 10 July 2021. 
Foreign Ministry Spokesperson Wang Wenbin's Regular Press Conference. (2021, July 5), retrieved from https://www.fmprc.gov.cn/mfa_eng/xwfw_665399/ s2510_665401/t1889823.shtml. Accessed 10 July 2021.

Foreign Ministry Spokesperson Zhao Lijian's Regular Press Conference. (2021, July 12) Retrieved from https://www.fmprc.gov.cn/mfa_eng/xwfw_665399/s2510_ 665401/2511_665403/t1891450.shtml. Accessed 20 July 2021.

Fu, D. (2021, February 9). How the Chinese state mobilized civil society to fight COVID-19. Brookings Institution, retrieved from https://www.brookings.edu/ blog/order-from-chaos/2021/02/09/how-the-chinese-state-mobilized-civilsociety-to-fight-covid-19/. Accessed 10 July 2021.

Kato, Y. (2020, May 21). COVID-19 and the Implementation of Xi Jinping's MajorPower Diplomacy. Asia Global Online, retrieved from https://www.asiaglobal online.hku.hk/covid-19-and-implementation-xi-jinpings-major-powerdiplomacy. Accessed 10 July 2021.

Kato, Y. (2019, March 7). What is Xi Jinping's Major Power Diplomacy? Asia Global Online, retrieved from https://www.asiaglobalonline.hku.hk/xi-jinping-chinamajor-power-diplomacy. Accessed 10 July 2021.

IMF. (2020, December 2). Staff Report for the 2020 Article IV Consultation- People's Republic of China. International Monetary Fund, Washington, D.C. U.S.A, retrieved from https://www.imf.org/en/Publications/CR/Issues/2021/01/06/ Peoples-Republic-of-China-2020-Article-IV-Consultation-Press-Release-StaffReport-and-49992. Accessed 10 July 2021.

Li, C. (2016). Chinese Politics in the Xi Jinping Era. Washington, D.C. Brookings Institution Press

Li, K. (2020, May 22). Report on the Work of the Government. Beijing, China, retrieved from http://english.www.gov.cn/premier/news/202005/30/content _WS5ed197f3c6d0b3f0e94990da.html. Accessed 5 July 2021.

McGregor, R. (2020, July 31). Inside China's Coronavirus Response. Lowy Institute, retrieved from https://www.lowyinstitute.org/publications/inside-chinacoronavirus-response. Accessed 5 July 2021.

Ministry of Foreign Affairs of China. (2021, May 21). Xi Jinping Attends and Delivers an Important Speech at the Global Health Summit. Retrieved from https:// www.fmprc.gov.cn/mfa_eng/zxxx_662805/t1877884.shtml. Accessed 5 July 2021.

Ministry of Foreign Affairs of China. (2020, May 9). Reality Check of US Allegations Against China on COVID-19, retrieved from https://www.fmprc.gov.cn/mfa_ eng/zxxx_662805/t1777545.shtml. Accessed 5 July 2021. 
National Health Commission of the People's Republic of China. (2021, March 12). Overview of the national epidemic situation of notifiable infectious diseases in 2020, retrieved from http://www.nhc.gov.cn/jkj/s3578/202103/f1a448b7df7d 4760976fea6d55834966.shtml?ivk_sa=1024320u. Accessed 5 July 2021.

Shambaugh, D. (2016). China's Future. Malden. Polity Press.

World Health Organization. (2021, March 30). WHO-convened global study of origins of SARS-CoV-2: China Part. Geneva, Switzerland, retrieved from https:// www.who.int/publications/i/item/who-convened-global-study-of-origins-ofsars-cov-2-china-part. Accessed 5 July 2021.

Xi, J. (2020, May 18). Fighting COVID-19 Through Solidarity and Cooperation Building a Global Community of Health for All. China's Diplomacy in the New Era, retrieved from http://en.chinadiplomacy.org.cn/2021-01/27/content_7715 8877.shtml. Accessed 5 July 2021.

Xinhua. (2020, February 23). Xi Focus: Xi stresses unremitting efforts in COVID-19 control, coordination on economic, social development. Retrieved from http://www.xinhuanet.com/english/2020-02/23/c_138811286.htm. Accessed 5 July 2021. 